\title{
Demokrat Parti Döneminde Kıbrıs Sorunu
}

\author{
The Cyprus Issue During Democrat Party Rule \\ Dr. Öğr. Üyesi Yakup KAYA ${ }^{1}$, Yüksek LisansÖğrencisi Bülent YETER ${ }^{2}$
}

\begin{abstract}
Özet
Kıbrıs sorunu on yıllardır Türk dış politikasının temel problematik alanlarından birisini teşkil etmektedir. Lozan Barış Antlaşması'na göre Kıbrıs, İngiltere'nin hâkimiyetinde kalmış ve bu nedenle Türkiye daha sonraki vetirede Kıbrıs'a müdahale etmeyi düşünmemiştir. İkinci Dünya Savaşı'ndan sonra, İngiltere'nin politikasını değiştirip hâkimiyetindeki topraklardan yavaş yavaş çekilmeye başlaması üzerine, Kıbrıs'ta Türkiye ve Yunanistan'ın da yer aldığı bir nüfuz mücadelesi başlamıştır. İngiltere'nin Adayı tahliye planı gündeme gelince Türkiye tarihsel, kültürel, demografik, coğrafi ve stratejik unsurların etkisi çerçevesinde Kıbrıs sorunuyla daha yakından ilgilenir hale gelmiştir. Demokrat Parti döneminin en önemli dış politika konularından birisi kuşkusuz Kıbrıs sorunudur. Söz konusu dönemde, Kıbrıs'ta iki toplumlu devlet yapısının temelleri atılmıştır. Türkiye öncelikle statükoyu devam ettirmek istemiştir. Bu olmazsa adanın tamamının kendisine verilmesi gerektiği görüşünü savunmuştur. $1955^{\prime}$ ten sonra da Adanın taksimi tezi ön plana çıkmıştır. Özellikle Londra Konferansı sonrasında Türkiye Kıbrıs sorununda resmen taraf haline gelmiştir. Lozan Barış Anlaşması ile Kıbrıs'ı İngiltere'ye bırakmak zorunda kalan Türkiye'nin, Demokrat Parti'nin izlediği dış politika ile Kıbrıs'ta tekrar hak sahibi haline geldiği görülmüştür. Makalede dönemin gazete arşivinden ve dönemle ilgili belli başlı telif ve tetkik eserlerden yararlanarak Demokrat Parti iktidarının Kıbrıs politikası incelenecektir.
\end{abstract}

Anahtar Kelimeler: Kıbrıs Sorunu, Demokrat Parti, Türk Dış Politikası, Londra Konferansı, 6-7 Eylül Olayları.

\begin{abstract}
Cyprus dispute remains to be one of the crucial issues in Turkey's foreign policy. According to Lausanne Peace Treaty, Cyprus remained under British rule and Turkey has limited its interventions over the island during the following developments. After the WWII, when Britain launched decolonization and abandoned former colonies, a dispute over the status of Cyprus between Turkey and Greece has been prompted. After Britain announced its intention t leave the island, Turkey became more interested in island due to its historical, cultural, demographic, geographical and strategical ties. Cyprus Dispute took the lion's share of Democrat Party's agenda-setting process. In the given period, the fundamentals of a bi-national administrative system in Cyprus are established. At first, Turkey was in favor of status quo. If not possible, she proclaimed that the entire island must be ceded to its government. After 1955, the claims proposing the division of the island are articulated. Turkey which was bound to surrender Cyprus to Britain with the Lausanne Peace Treaty turned out to be one of the guarantees of the island. The article aims at investigating the Cyprus policy of Democrat
\end{abstract}

\footnotetext{
${ }^{1}$ Necmettin Erbakan Üniversitesi Sosyal ve Beşeri Bilimler Fakültesi, ykaya@konya.edu.tr, Orcid ID: orcid.org/0000-00029951-2844

${ }^{2}$ Necmettin Erbakan Üniversitesi, Sosyal Bilimler Enstitüsü, bulentyeter@hotmail.com, Orcid ID: orcid.org/0000-0003-38279679
} 
Party through contemporary newspapers, along with leading studies over the issue and the secondary sources.

Keywords: Cyprus Dispute, Democrat Party, Turkish Foreign Policy, London Conference, 6-7 September Incidents.

\section{Giriş}

1950'den itibaren kamuoyunda yer edinmeye başlayan Kıbrıs sorunu, başlangıçta Türk-Yunan dostluğu çerçevesinde Demokrat Parti Hükümetlerince ikinci planda tutulmaya çalışılmış, ancak Türkiye'nin soruna resmen taraf olmasıyla birlikte iki ülke arasındaki ilişkilerin seyrini belirlemiştir (Oran, 2009: 593). Bu sebeple tarihi sürecin iyi bilinmesi ve ona göre hareket edilmesi gereklidir. Bu meyanda Kıbrıs'ın tarihi arka planına kısaca değinmek, konunun daha iyi kavranması açısından fayda sağlayacaktır (Sakin, Dokuyan, 2013: 13).

16. Yüzyılda Venedik hâkimiyetinde bulunan Kıbrıs, stratejik ve ticari konumundan dolayı Osmanlı Devleti'nin yakından ilgilendiği bir yer olmuştur. Gerekli hazırlıkları yaptıktan sonra harekete geçen Osmanlı Devleti, 1571 yılında Kıbrıs'1 fethetmiştir (Alasya, 1988: 10-15). 19. Yüzyılın son çeyreğine kadar Osmanlı Devleti egemenliğinde kalan Kıbrıs, 4 Haziran 1878 tarihinde imzalanan Kıbrıs Antlaşması ile İngiltere'ye idari olarak devredilmiştir (Zia, 1975: 38-40). Birinci Dünya Savaşı'nda Osmanlı Devleti'nin Almanya'nın yanında savaşa girmesi üzerine İngiltere, Kıbrıs'1 tek taraflı olarak ilhak etmiştir (Cam, 1966: 55-60). Sadece protesto etmekle yetinebilse de Osmanlı Devleti bu ilhakı, Lozan Antlaşması'na kadar tanımamıştır. Kıbrıs, Lozan Antlaşması ile artık tamamen İngiltere'ye bırakı1mıştır (Meray, 2001: 6-7).

Kıbrıs İngiltere'ye devredildikten sonra Türkiye, Kıbrıs konusunda herhangi bir girişimde bulunmayı düşünmemiştir. Kıbrıs toprağına İngiltere'nin hâkimiyetinde bulunan bir yer olarak bakılmış ve İngiltere'nin bu hakkını başka bir güce devretmek niyetinde olmadığı takdirde Türkiye'nin bir Kıbrıs sorunu olmadığ1 dile getirilmiştir (Bağc1, 2007: 103). Şunu ifade etmek gerekir ki 1928'den itibaren Yunanistan, Kıbrıs'1 ilhak projesini (Enosis) bir devlet politikası haline getirmesine rağmen Türkiye, Kıbrıs ile ilgili gelişmeleri İngiltere'nin bir iç sorunu olarak görmüştür. Başka bir deyişle Kıbrıs, Türkiye için henüz bir dava haline gelmemiştir (Dikerdem, 1977: 122-123).

1950’li yıllarda dünya yeniden biçimlenmiştir. Bu biçimlenme içinde İngiliz İmparatorluğu da çoktan geri çekilme hareketlerini başlatmıştır. İngiltere, eski imparatorluk topraklarını gerçek sahiplerine, yani yerel halklara bırakırken sıra Kıbrıs'a da gelecektir (Manisal1, 2012: 12). İngiltere'nin İkinci Dünya Savaş1 sonrasında sömürgelerinden çekilmeye başlamış olmasını fırsat bilen Kıbrıs Rumları adanın bağımsızlığı için harekete geçmişlerdir. Esas hedef, adanın Yunanistan'a ilhakıdır. Yunan Kralı Naibi Damaskinos, 12 Ada ile birlikte Kıbrıs'ın da kendilerine verilmesi gerektiği görüşünü 1945 yılında İngiltere'ye yaptığı ziyarette basın yolu ile kamuoyuna duyurmuştur. 1931 yılında çıkardıkları isyan sebebiyle Kıbrıs dışına sürülmüş olan papazların Kıbrıs'a dönüşüne 1947 'de adaya vali olarak atanan Lord Winster'in izin vermesi, bu yeni dönemin habercisi olarak algılanabilir. Valinin öncülüğünde, Başyargıç Sir Edward Jackson başkanlığında oluşturulan bir Danışma Meclisi vasıtasıyla, İngiltere'nin adaya özerklik verme çalışmalarına başladığı görülmektedir (Kapc1, Sakin, 2015: 239). 
Rumların Enosis çabaları adadaki Türkleri rahatsız etmiştir. 28 Kasım 1949'da birincisi, daha geniş katılım sağlanmak suretiyle 11 Aralık 1949'da ikincisi düzenlenen miting, Lefkoşa'da bulunan Ayasofya Meydanı'nda gerçekleştirilmiştir. 12 Ocak 1950'de Atina Üniversitesi öğrencilerinin Enosis için tertip ettikleri bir mitingle Yunan halkının Kıbrıs'ın Yunanistan'a bağlanması hususundaki tavrı dünyaya ilan edilmiş, 15-22 Ocak 1950'de Rum Kilisesi, Adayı Yunanistan'a bağlamak amacıyla bir halk oylaması (plebisit) düzenlemiştir. Bu oylamada halka Enosis'i istiyoruz ya da istemiyoruz cevaplarını içeren iki seçenek sunulmuştur. Plebisitin sonunda Adada bulunan 224.757 kişiden ibaret Rum ahalinin \% 95,7'sini oluşturan 215.108 kişi istiyoruz cevabını vermiştir (Kapc1, Sakin, 2015:139).

\section{Demokrat Parti İktidarının Kıbrıs Sorununa Bakışı (1950-1955)}

Demokrat Parti, 14 Mayıs 1950 seçimleri ile iktidara geldikten sonra Yunanistan ile iyi komşuluk ilişkilerine devam etmek için, Kıbrıs konusunda iki ülke arasında herhangi bir sorun olmadığını dile getirmiştir. Kıbrıs hala İngiltere'nin egemenliği altında olduğundan, Demokrat Parti hükümeti bu sorunu gündeme getirmekten en azından o an için kaçınmıştır. Ancak koşullar değiştiğinde tavrını da değiştireceğini belirtmekten de geri durmamıştır. Demokrat Parti Dış İşleri Bakanı Fuat Köprülü’nün şu açıklamaları bunu göstermektedir: "Hiç yokken ortaya bir Kıbrıs sorunu çıkarmaktan vazgeçin. Çıkarırsanız bizi karşınızda bulacaksınız. Kıbrıs'ta nedenlerini bizim anlayamadığımız yahut da anlamak istemediğimiz emellerinizi nasıl olsa gerçekleştiremeyeceksiniz. Türkiye bu izni size asla vermeyecektir. Resmi beyanlarımızda Türkiye için Kıbrıs diye bir dava yoktur diyeceğiz. Fakat ister istemez bu sabrin da bir sonu olacaktır." (Bağc1, 2007: 103).

Türkiye'nin böyle bir politika izlemesinde, Sovyet yayılması ve baskısına karşı kendi varlığının ve güvenliğinin sürekliliğini sağlama güdüsü önemli bir rol oynamıştır. Yine Türkiye 1952-1954 yılları arasında NATO'ya girmekle elde edilen güvenliğin daha da genişletilmesi ve güçlendirilmesi hamlesine yönelmiştir. Yunanistan'ın İngiltere'ye başvurarak adayı resmen istemesine karş1, Türkiye'nin Yunanistan ile Balkan İttifakını gerçekleştirmeye çok daha önem vermesi, Kıbrıs sorununda başlangıçta pasif kalmasına ve mesafe kaybetmesine neden olmuştur (Uçarol, 1995: 742-743).

Kıbrıs sorunu 16 Ağustos 1954 tarihinde, Yunanistan tarafindan bir şikâyet konusu olarak ilk defa Birleşmiş Milletler Genel Kurulu önüne taşınınca uluslararası bir sorun haline gelmiştir. Yunanistan, bu başvurusunda Kıbrıs Adası halkının kendi geleceğini kendilerinin tayin etmesi (self determinasyon) ilkesinin uygulanmasını istemiştir. Birleşmiş Milletler, sorunun görüşülmesini gündeme almasına rağmen Yunanistan'ın isteğini reddetmiştir (Uçarol, 1995: 741). Bu karar Başbakan Adnan Menderes'i oldukça memnun etmiştir ki 18 Aralık 1954 tarihinde Menderes verdiği bir demeçte, "Bu mesele tamamıyla kapandığ için artık müttefikimiz Yunanistan ile aramızdaki dostluğun gölgelenmemesine dikkat ve itina göstermek zamanı gelmiş bulunuyor" (Armaoğlu, 2000: 531) değerlendirmesinde bulunmuştur.

Menderes, olayı bu minvalde değerlendirse de Yunanistan'ın Kıbrıs üzerindeki istekleri resmi bir politika olarak ortaya çıkıp sorun uluslararası bir şekil alınca ve ardından İngiltere'nin Kıbrıs üzerindeki egemenliğinden vazgeçebileceği ihtimali belirince Demokrat Parti, Kıbrıs'la ilgilenmeye başlamıştır (Sakin, Dokuyan, 2013: 44). Bu doğrultuda yapılan 
ilk hareket ise, Fatin Rüştü Zorlu'nun hükümet tarafından Kıbrıs sorunu ile ilgilenmesi için görevlendirilmesi olmuştur (Tuna, 2010: 173).

Zorlu görevlendirildikten hemen sonra Dış İşleri Bakanlığı'nda bir Kıbrıs Komisyonu kurmuştur. Zorlu başkanlığındaki bu komisyon, Genelkurmay İkinci Başkanı Rüştü Erdelhun, Dış İşleri Bakanlığı Genel Sekreteri Muharrem Nuri Birgi, Atina Büyükelçisi Settar İlksel, Dış İş̧leri Bakanlığı Müsteşarı Orhan Eralp ve Büyükelçi Mahmut Dikerdem'den meydana gelmiştir. Bu komisyonun görevi, Türkiye'nin Kıbrıs hakkındaki resmi düşüncesini ve Demokrat Parti’nin Kıbrıs stratejisini ve taktiğini geliştirmek olarak tespit edilmiştir. Komisyon, DP'nin Kıbrıs stratejisinin kesin olarak ortaya çıkarılmasına kadar iki temel prensip belirlemiştir. Buna göre birincisi, dünya kamuoyu dokümanlar aracılığıyla Türkiye'nin de Kıbrıs'ta aynı Yunanistan gibi haklara sahip olduğuna ikna edilmelidir. İkincisi ise, Kıbrıs sorununun kesin olarak çözümüne kadar Kıbrıslı Türklerin Yunanistan'ın baskılarına karşı koyabilmek için desteklenmeleri sağlanmalıdır. Ardından komisyon, İngilizce ve Fransızca tercümelerini yaptırdığı ve Kıbrıs'ın Türkiye için önemini tarihsel, coğrafi, etnolojik, kültürel, siyasi ve askeri açılardan ele aldığı bir 'Beyaz Kitap' hazırlayarak Türkiye'nin dış temsilciliklerine göndermiştir (Bağc1, 2007: 109).

Kıbrıs konusunda bir başka gelişme de bu konuda özel olarak görevlendirilen Fatin Rüştü Zorlu'nun 27 Temmuz 1954 tarihinde bizzat Başbakan Adnan Menderes tarafindan Dış İşleri bakanlığına getirilmesi olmuştur. Fuat Köprülü ise Başbakan yardımcılığına atanmıştır. Zorlu bu konuda verdiği demeçte, Kıbrıs'ın durumunun Türkiye'yi çok yakından ilgilendirdiğini ve Adanın hukuki statüsü değişecekse Türkiye'nin düşüncesinin alınmadan bunun gerçekleştirilemeyeceğini açıklamıştır (Sakin, Dokuyan, 2013: 44).

\subsection{Londra Konferansı}

Birleşmiş Milletler'in yukarıda bahsedilen ret kararı Kıbrıs uyuşmazlığını sona erdirememiş̧ir. Aksine Yunan isteğinin reddedilmesi üzerine Rumlar 1 Nisan 1955'te Kıbrıs'ta EOKA (Ellonikos Organismus Kypriakan Aganista) isimli yeraltı örgütünü kurarak önce İngilizler sonra da Türklere karşı tedhiş hareketlerine başlamışlardır. Kıbrıs Rum Milli Mücadele Örgütü anlamına gelen EOKA'nın amacı önce İngilizleri Ada'dan atmak sonra da topyekûn bir imha hareketi ile Türk halkını yok ederek Kıbrıs'1 Yunanistan'a bağlamaktır (Koç, 2006: 76-77). Kıbrıs'ta olayların böylece bir bunalım haline dönüşmesi üzerine İngiltere (Uçarol, 1995: 743). 'Doğu Akdeniz Savunması ve Kıbrıs Sorununu' görüşmek maksadıyla 30 Haziran 1955 tarihinde Türk ve Yunan hükümetlerine resmen çağrıda bulunarak Kıbrıs konusunu çözümlemek üzere Londra'da bir konferans toplamaya karar vermiştir. Üç hükümetin ortak kararıyla konferans tarihi 29 Ağustos 1955 olarak kabul edilmiştir (Sakin, Dokuyan, 2013: 54-55).

İngiltere bu konferans aracılığıyla sorunun Birleşmiş Milletlere taşınmasını engellemenin yanı sıra, Adada yaşayan halkların birbirlerine zarar vermesinin önüne geçmeye çalışmıştır. Konferansın İngiltere açısından diğer bir amacı da, Türkiye'yi kendi yanına çekerek Rumlar tarafından İngilizlere isnat edilen sömürgecilik yaftasından kurtulmaktır. Aslında İngiltere, iki devleti birbirine karşı kullanarak hem zaman kazanmak hem de daha fazla ödün koparmak amacındayd. Türkiye, taraf olduğunu kabul ettirmek için iyi bir firsat kabul ettiği bu konferans davetini derhal, Yunanistan ise Türkiye'nin taraf olmasından korktuğu için tereddütle kabul etmiştir (Sakin, Dokuyan, 2013: 55) 
Kıbrıs Sorunu milli bir dava haline dönüşmüştür. Türkiye'nin hemen hemen tüm bölgelerindeki çeşitli gençlik dernekleri gösteriler düzenlenmesi için başvurular yapmaya başlamışlardır. Basın, bilhassa da Hürriyet Gazetesi, bu milli sorunun sözcülüğünü üstlenmiştir (Bağc1, 2007: 109).

Nihayet Londra Konferansı 29 Ağustos 1955 'te toplanmıştır. İngiltere, Yunanistan'a bir ödün olmak üzere Adaya özerklik vermeyi teklif etmiş; Yunanistan ise self determinasyon talebini dile getirmiş ve bu yolla da adanın kendisine katılmasını hedeflemiştir(Uçarol, 1995: 744).

Fatin Rüştü Zorlu ise konferans esnasında Türk tezini şu delillerle savunmuştur: Türkiye gerçi Lozan Antlaşması ile adadaki haklarından vazgeçmiştir (16. madde) ancak aynı antlaşmanın 20. ve 21. Maddeleri Kıbrıs'a özel bir statü tanımıştır. Buna göre 20. Madde ile Türkiye hükümranlık haklarını İngiltere'ye devretmiştir. 21. Madde ise Kıbrıs'ta yaşayan toplulukların Lozan Antlaşması'nın imzalanmasından sonraki iki yıl içerisinde İngiliz ya da Türk vatandaşlığını kabul etme hakkını tanımıştır. Türk tezine göre Türkiye'nin Adanın geleceğiyle ilgilenmesinin temelinde tarihsel, coğrafi, etnik ve stratejik faktörler yatmaktaydı. Kıbrıs adası yaklaşık 400 yıl Osmanlı Devleti'nin egemenliği altında (15711914) bulunmuş ve tarihte hiçbir zaman Yunan egemenliği altına girmemiştir. Adanın Türkiye'nin güney kıyılarına uzaklığ $70 \mathrm{~km}$ iken, Yunanistan'a olan uzaklığ1 1000 kilometreyi bulmaktadır. Birinci Dünya Savaşı'na kadar Türkler Adadaki nüfusun çoğunluğunu teşkil etmişlerdir. Kıbrıs her şeyden önce stratejik nedenlerden ötürü Türkiye için vazgeçilemez bir konuma sahiptir. Türk tezine göre İngiltere Adanın hükümranlığından vazgeçme niyetinde ise, Kıbrıs Adasının asıl sahibine (yani Türkiye'ye) devredilmesi gerekmektedir. Yunanistan Kıbrıs sorununda Türkiye'nin müzakere ortağı olarak görülmemiştir (Bağc1, 2007: 111-112).

3 Eylül'de Londra'da bir basın toplantısı yapan Dış İşleri Bakanı Zorlu, "Hala muayyen emellere ulaşmak için teşebbüse geçecek olanlar, bunun bütün mesuliyetini üzerine alarak hareket edebilirler" ifadeleriyle Yunanistan'a bir nevi ihtar vermiştir. Konferans devam ederken 6 Eylül'de İngiltere Dış İşleri Bakanı Harold Macmillan kendi planını öne sürmüştür. $\mathrm{Bu}$ plana göre Kıbrıs'ta bir anayasa uygulanacak ve bu anayasa Kıbrıs'ın muhtariyetini ve otonomisini sağlayacaktır (Koç, 2006: 79).

Görülüyor ki üç devletin görüşlerinin bağdaştırılması mümkün değildir. Yani konferansın sonuçsuz kalacağı aşikârdır. Tam da bu sırada Türkiye'de 6 Eylül 1955 gecesi meydana gelen olaylar Yunan temsilcisinin konferansı derhal terk etmesine ve görüşmelerin sonuçsuz kalmasına neden olmuştur. Konferansın tek olumlu yanı, Türkiye'nin Kıbris konusunda söz sahibi bir konuma gelmesi ve kuvvetli bir tezi olan taraf olarak dünya kamuoyuna açıklanmış olmasıdır. Üstelik Yunanistan, bu konferansta Türkiye'nin karşısına oturmakla bu gerçeği ister istemez kabul etmiştir. Konferans ayrıca Kıbrıs sorununun Türkiye olmadan çözülemeyeceğini ortaya koymuştur (Sakin, Dokuyan, 2013: 68-69).

\subsection{6-7 Eylül Olayları}

Kıbrıs Sorununun Türkiye basınında sürekli gündeme getirildiği bir ortamda o zamana kadar Enosis taleplerinde bulunan Rumların bu defa 28 Ağustos 1955 tarihinde, yani Londra Konferansı toplanmadan bir gün önce, Kıbrıs'ta yaşayan Türkleri tamamen 
katledecekleri haberleri dilden dile dolaşmaya başlamıştır. Doğal olarak bu söylentiler Türk halkını patlamaya hazır bir bomba haline getirmiştir. Ayrıca 5 Eylül gecesi, Mustafa Kemal Atatürk'ün Selanik'teki evine ve aynı bahçe içerisinde bulunan Türk konsolosluğuna bomba atılması da olayların fitilini ateşlemiştir. Bomba haberi ilk olarak 6 Eylül günü radyoda 13.00 haberlerinde verilmiştir (Demirer, 2006: 76).

Ardından bu haber İstanbul Ekspres gazetesinin ikinci baskısında 'Atamızın evi bomba ile hasara uğradı' manşetiyle yer almış ve sabaha karşı meydana gelen bu menfur bomba olayının infiale yol açtığı ifade edilmiştir. Yine gece yarısını 4 dakika geçe meydana gelen olay sonrasında evde büyük bir hasarın oluştuğu, olaydan sonra Yunan polisinin derhal harekete geçerek 5 şüpheli şahsı nezaret altına aldığı yazılmıştır (İstanbul Ekspres, 1955: 1). Aynı gazetede bir de Yunan Resmî Tebliği yayınlanmıştır. Tebliğ aynen şöyledir: "Yunan Hükümeti husule gelen zararı tazmin edecektir. Hadisenin müsebbiplerinin aranmasına başlanmıştır. Bu işi yapan muhakkak ki hakiki bir Yunanlı değildir." Diğer taraftan Atina çevreleri bu hadisede bir komünist parmağı olması ihtimalinden de ehemmiyetle bahsetmektedirler. Yunan polisi şüpheli şahısları aramaya başlamış ve ilk olarak beş kişiyi tevkif etmiştir. Bunun bir komplo olması ihtimali üzerinde de ayrıca durulmuştur. Hadisenin en mühim bir cephesi de Kıbrıs'ta tedhiş hareketlerine girişmiş kimselere daha fazla cesaret vererek işi büyütmelerine sebep olacağı noktasıdır. Hatta bu işi yapanların EOKA teşkilatına mensup ve Makarios'un hizmetindeki kimselerden olması ihtimali de mevcuttur (Istanbul Ekspres, 1955: 1).

İstanbul Ekspres gazetesindeki haber ile ilgili olarak da Menderes şu ifadeleri kullanmıştır: "İstanbul Valisi acele odama geldi, yanında İstanbul Emniyet Müdürü de vardl. Istanbul Ekspres adındaki gazeteyi bana uzattılar. Okuyunca kan beynime çıtk. Selanik'te Atatürk'ün evine Yunanlılar bomba atmışlardl. Emniyet, istihbarat kaynaklarına göre bazı kuruluşların bu olayı protesto etmek üzere hazırlık yaptığı haberini almıştl. Benden talimat bekliyorlardl. Dikkatli olalım, polis alarma geçsin, bu aşamada tam olarak sessiz kalmak iyi olmaz. Ancak gençlik galeyana gelebilir, kontrolü elden çıkarmayın” (Tuna, 2010: 204).

Menderes sözlerinde haklı çıkmıştır. Zira gazetenin İstanbul sokaklarında dağıtılması ile İstanbul büyük bir duyarlılık içerisine girmiştir. Hemen akabinde gençleri örgütleyen 'Kıbrıs Türktür Cemiyeti', bomba olayını protesto etmek amaciyla Taksim'de miting düzenlemeye koyulmuştur. Bu gelişmeler 6 Eylül gecesi patlak verecek olayların önünü açan bir nitelik almıştır (Milliyet, 1955: 3). Bu andan itibaren şehrin hemen her yerinde 200-300 kişilik gruplar halinde yürüyüşler yapılmaya başlanmıştır. Sokaklardaki dükkân ve mağazaların cam ve çerçeveleri kırılmıştır. Beyoğlu'nda Rumlara ait iş yerleri ve dükkanlar hedefe alınarak buralara zarar verilmiştir. Saat 23.00 'ten sonra 1. Ordu'ya bağlı birlikler harekete geçerek olaylara müdahale etmişlerdir. Olaylar ancak gece yarısından sonra 02.30 sıralarında kontrol altına alınmıştır (Karakuş, 1977: 277-278). Olaylarla ilgisi olduğu düşüncesi ile 8 Eylül'de Kıbrıs Türktür Cemiyeti kapatılmıştır. 10 Eylül'de de Menderes, İç İşleri Bakanı Namık Gedik'in istifasını istemiş o da istifa etmeyi sessizce kabul etmiştir (Tuna, 2010: 206).

Daha sonra Türkiye Büyük Millet Meclisi, Cumhurbaşkanı Celal Bayar'ın "Hükümetçe İstanbul, İzmir ve Ankara vilayetlerinde Örfi İdare ilan edilmiş olduğundan Teşkilatı Esasiye Kanununun 86. Maddesine tevfikan TBMM'yi 12 Eylül 1955 Pazartesi günü saat 15.00'da içtimaa davet ettim" sözlerinin yazılı olduğu 7 Eylül 1955 tarihli 
Cumhurbaşkanlığg tezkeresi üzerine (TBMM Zabıt Ceridesi, X: 668) 12 Eylül'de olağanüstü olarak toplanmıştır.

Görüşmeler sırasında Menderes rahatsız olduğunu belirterek kendisi adına Fuat Köprülü’nün konuşmasını istemiştir. Sözlerine “Bunun hakikaten tasviri çok zordur. Hadise hakikaten feci bir felakettir" (Tan, 1955: 7) diye başlayan Köprülü, şöyle devam etmiştir: "Arkadaşlar şundan bundan, emniyet kuvvetlerinin zafiyetinden, vaktinde haberdar olamadiğından bahsettiler. Şunu söyleyeyim ki bu hadiseden hükümet evvelce haberdardl. Ona göre bazı tertibat da almıştı. Fakat bu hadisenin günü ve saati muayyen değildi ve bu bütün gayretlere rağmen adeta bir baskin şeklinde her tarafta birden tecelli etmiștir. Hatırlarsinız tarihte buna benzer hadiseler çok olmuştur. Bunun en yakın misali Pearl Harbour'da Amerikan Donanmasının maruz kaldı ̆̆ felakettir. Bütün istihbarat vasıtalarının envaina malik olan maddi ve manevi her şeye malik bulunan büyük bir devlet, adaya gelip baskın yapıncaya kadar Japon donanmasinin hareketinden haberdar olamamıştır. Binaenaleyh tarihte emsali çok olan bu gibi gafletlere tesadüf edildiğini unutmamak lazımdır. Sonra bunda elbette birtakım mesuller de vardır. Tahkikat başlamıştır. Tahkikatın neticesinde bu mesuller, hadisenin failleri teker teker en ufağından en büyüğ̈̈ne kadar meydana çıkarılacaktır..." (TBMM Zabıt Ceridesi, X: 684).

Köprülü'nün ifadeleri üzerine söz almak zorunda kalan Menderes, Kıbrıs sorunu dolayısıyla kışkırtılan halkın olaylara neden olduğunu, Türklerin Kıbrıs'ta katledileceği haberlerinin de kışkırtıcı rol oynadığını, Selanik'teki bomba olayının ardından ise halkı galeyana getiren kötü niyetli kişilerin aracılığıyla olayların istenmeyen boyutlara taşındığını belirtmiştir (Akın, 2006: 180-181). Olayların bir anda artması karşısında polisin silah kullanmakta tereddüt ettiğini, olaylarla ilgili tahkikatın detaylıca yapılacağını, suçluların bulunacağını ve zarar görenlerin zararlarının karşılanacağını da sözlerine eklemiştir (Güven, 2009: 47).

Yukarıdaki Meclis konuşmasıyla ilgili olarak Köprülü, Yassıada duruşmalarında İstanbul'daki gergin havayı bildiğini, bu yüzden tedbirlerin önceden alınarak poliste izinlerin kaldırıldığını, hükümetin haberi vardı derken de kendi adına değil, Başbakan adına konuştuğunu ve onun bilgisi olduğunu, kendisinin olaylarla hiçbir alakasının bulunmadığını söylemiştir (Milliyet, 1960: 5). Aynı duruşmalarda Menderes, Köprülü’nün “Bu hadiselerden hükümet haberdardl" sözlerinin gerçeği anlattığını zira 26 Ağustos tarihinden itibaren ordu birliklerinden yardım istendiğini, izinlerin kaldırıldığını belirtmiş, haberimiz vardı denmesinden anlaşılması gerekenin bu olduğunu söylemiştir (Milliyet, 1960: 1).

Köprülü olaylarla ilgili olarak sonraki dönemlerde yaptığı konuşmalarında 1955 Eylül ayında İstanbul'a bir iş için tesadüfen geldiğini, hadiselerin başladığg sırada Anadolu yakasında olduğunu söylemiştir (Milliyet, 1960: 5).

Cumhurbaşkanı Celal Bayar ve Başbakan Adnan Menderes ile olayları görmüş olmalarına rağmen Haydarpaşa'ya geçtiklerini, hatta saat 20.00'de Menderes'in Londra'da bulunan Dış İşleri Bakanı Zorlu ile telefonda bu konuyla ilgili konuştuklarını ifade etmiştir (Milliyet, 1960: 6). Köprülü olayları İstanbul Ekspres gazetesinden öğrendiğini, İzmit'e geldikleri sırada Mükerrem Sarol'dan olaylar hakkındaki telgrafın alındığını belirterek bundan sonraki gelişmeleri Yassıada duruşmalarında tanık sıfatıyla şu şekilde anlatmıştır: 
"Ben kendilerine bunları görmediniz mi deyince talebe nümayişleri şeklinde dediler. Sinirlendim. Geri dönülmesi icap ettiğini bildirdim. Teklifim kabul edildi ve geri döndük. Hatta İstanbul hudutlarında birkaç çapulcu grubu biz dağıttık. Türkiye'nin itibarı kırılmıştı. Mal ve gayrimenkule önceden tasarlanmış ve tedarik edilmiş muayyen vasitalarla hücum edilmiş ve buna milli nümayiş havası verilmişti. Bu muayyen vasıtaların kullanılması bende bunun bir tahrik neticesi olduğu kanaatini uyandırdı. Gayrimenkule yapılan hücumlarda daha önceden tespit edilmiş bir durum vardl. Bunun bir anda yapılmasına imkân yoktu" (Milliyet, 1960: 5).

Böyle bir kargaşa gecesinin ardından Demokrat Parti, zarar görenlerin zararlarının telafisinin çarelerini aramaya başlamıştır ve suçluların peşine düşmüştür. Ancak hükümetin yaptırdığı yargılamalar sonrasında bir suçlu bulunamamıştır (Sakin, Dokuyan, 2013: 219).

\section{6-7 Eylül Olayları Sonrasında Demokrat Parti’nin Kıbrıs Politikası}

Londra Konferansı'ndan istediği sonucu alamayan İngiltere, kendi görüşüne dayanarak Adaya muhtariyet vermek üzere hazırlıklara başlamıştır (Koç, 2006: 79).

Kıbrıs'a vali olarak Eylül 1955 sonunda sabık Genelkurmay Başkanı Mareşal Sir John Harding'i atamıştır. Atamayı takip eden süreçte İngiltere'nin yürüttüğü politika, İngiliz Büyükelçiliği'nin 1956 yılı raporundan anlaşılmaktadır. Raporda İngiliz Hükümetinin Adadaki Türk ve Rum toplumlarına eşit olarak self determinasyon uygulamasının prensiplerini içeren politik duruşu yansıtılmıştır. Taksim ise olası nihai bir çözüm olarak kabul edilmiştir (Yüksel, 2011: 121).

$\mathrm{Bu}$ sıralarda ise Kıbrıs'taki Rum tedhiş hareketleri yoğunlaşmıştır. Amaçları, Kıbrıs sorununu uluslararası bir konu haline getirmek ve İngiliz kamuoyunu etkileyerek İngiliz hükümetine isteklerini zorla kabul ettirmekti. Diğer yandan da Türklerin İngiliz güvenlik kuvvetleri içinde görev almalarını önlemek ve daha sonra da Türk toplumunu yıldırarak Kıbrıs'tan ayrılmasını sağlamaktı. Rumların böylece Türk köylerine saldırmaya ve Türkleri öldürmeye başlamaları üzerine Kıbrıs'taki uyuşmazlık toplumlar arasında bir iç savaş haline dönüşmüştür. Bu da Türkiye ve Yunanistan'ın karşıllklı olarak birbirlerini suçlamalarına neden olmuştur (Uçarol, 1995 : 744).

Böyle bir ortamda gelinen 1956 yılı olaylarla dolu bir yıl olarak Kibris anlaşmazlı̆̆ının tarihine geçmiştir (Bağcı, 2007 : 116). Harding, Kıbrıs'a geldikten sonra 1956 Ocak ayından itibaren Kıbrıs Rum halkının temsilcisi sayılan Başpiskopos III. Makarios (Michael Christodoulos Moskous) ile görüşmelere başlamıştır (Göktepe, 2002: 946). Görüşmelerde, İngiltere self determinasyon prensibini tanımaya eğilim göstermiştir. İngiltere tarafindan Kıbrıs'a bir muhtariyet anayasası verilmesi amacinı güden bu müzakerelerde, Kıbris Valisi Mareşal Harding, Makarios'u böyle bir muhtariyet anayasasının hazırlanması için işbirliğine davet etmiştir. Ancak Demokrat Parti hükümeti böyle bir gelişme karşısında endişelenmiş ve derhal harekete geçerek Makarios'un Kıbrıs halkının temsilcisi olamayacağını belirtmiş ve Harding ile resmen müzakerelere girişmesine itiraz etmiştir. Ardından uygulanacak politika konusundaki şartlar şöyle dile getirilmiştir: "Hükümetimiz self determinasyon prensibini milletlerarasl bir prensip olarak kabul etmektedir. Fakat bu prensibin Kibris'ta tatbikine cevaz verilemeyeceği kanaatindedir. Hükümetimizin kanaatince Kıbrıs'ta idari muhtariyet gidilebilmesi için, her şeyden evvel, 
oradaki tedhişçiliğin bertaraf edilmesi, asayiş ve nizamın avdet etmesi ve muhtelif cemaatler arasındaki nefret havasının zail olması lazımdır” (Armaoğlu, 1963: 214).

DP'nin bu tavrına rağmen Makarios ile görüşmelerini sürdüren İngiltere, bu görüşmelerden bir sonuç çıkmayacağını anladığı anda Makarios ve üç arkadaşını EOKA'nın yöneticisi oldukları ve tedhiş eylemleri planladıkları gerekçesiyle Lefkoşa Uluslararası Havaalanında 9 Mart 1956'da tutuklamış ve Seychelles Adalarına sürgün etmiştir (Keser, 2007: 91-93). Ancak bu sürgünü müteakip EOKA’nın tedhiş hareketleri giderek daha da artmıştır. Nitekim Lefkoşa yakınlarındaki iki Türk köyüne Rumlar saldırarak köyde yangınlar çıkarmışlar ve bir Türk'ü de öldürmüşlerdir. Bunun arkasından yine Rum tedhişçiler Baf'ta bir Türk polisini katletmişlerdir (Koç, 2006: 80).

Olayların böyle bir hal alması üzerine İngiltere Dışişleri Bakanı Selwyn Lloyd, 1113 Mart 1956 tarihleri arasında Ankara'yı ziyaret edip, Türk devlet adamları ile görüşmelerde bulunmuştur. Ziyarette Türkiye'yi teskin etmek amacı güdülmüştür. Çünkü hem Kıbrıs hem de Orta-Doğu sorunlarında İngiltere, Türk Hükümetinin işbirliğinin önemini düşünmeye başlamıştır (Kapcı, Sakin, 2015: 145). İngiltere bunlara rağmen Kıbrıs'a özerklik verilmesi yolundaki çalışmalarını sürdürmüştür. Statükonun devamında ssrar eden Türkiye, İngiltere'nin özerklik konusunda kararının kesinleşmesi üzerine bu oldubittiyi kabul ederek özerkliğe eğilim göstermeye başlamıştır. Çok geçmeden Kıbrıs Türklerinin yaşama ve özgürlük haklarını güvence altına alacak olan kendi özerklik önerilerini İngiltere'ye bildirmiştir. İngiltere de özerklik çalışmalarını hızlandırarak Temmuz 1956'da Lord Radcliffe'i bir anayasa hazırlamakla görevlendirmiştir (Uçarol, 1995: 745). Lord Radcliffe liberal bir anayasa hazırlamak üzere Kıbrıs'a gelerek yüksek hükümet memurları ve Türk cemaati liderleri ile görüşmeler yapmıştır (Koç, 2006 : 81). Fakat hiçbir Rum muhatap bulamamıştır. Makarios'un sürgüne gidişinden sonra Rum toplumunun liderliği EOKA'nın eline geçmiş ve EOKA da Makarios sürgünden dönünceye kadar İngiliz yönetimiyle görüşmeyi reddetmiştir (Firat, 2002: 603).

Demokrat Parti hükümeti de Kıbrıs konusunda yeni bir isme yönelmiş ve Menderes, İsmet İnönü'nün yakın çalı̧̧ma arkadaşı Nihat Erim'i sorumlu temsilci olarak görevlendirmiştir. Ardından Erim'e Kıbrıs konusunda beş farklı alternatif sunulmuştur. Bunlar: 1. İngilizler Kıbrıs'ta kalsın. 2. Onlar çıkacaksa Ada bize verilsin. 3. Bu olmazsa Ada taksim edilsin. 4. Self determinasyon (özerklik) ve 5. Hiç arzu etmediğimiz şekil Adanın Yunanistan'a verilmesidir. Bu isteklerden ikincisi zaten o ana kadar savunulan bir tezdir. Ancak üçüncü istek yeni söylenen bir şeydi. Başbakan Menderes, Kıbrıs politikasını Adanın taksimi şeklinde değiştirmiş bulunmaktaydı (Bağc1, 2007: 59-60). Taksim yani adanın Türkiye ile Yunanistan arasında bölünmesi düşüncesini Ankara'da çıkan Forum Dergisi Temmuz 1955 'te ortaya atmıştır. Türkiye başlangıçta uzak durduğu bu düşünceye 1956 yılının sonlarından itibaren daha sıcak bakmaya başlamıştır (Fırat, 2002: 604).

Nihayet Lord Radcliffe hazırladığı muhtariyet anayasasını 12 Kasım 1956 tarihinde İngiltere Sömürgeler Bakanlığı'na sunmuştur (Koç, 2006 : 81). Radcliffe tarafından Kıbrıs için hazırlanan anayasa ikili salahiyet sistemini kabul etmiş ve adaya bazı sahalarda muhtariyet vermiştir. Buna göre İngiltere, savunma, dış ve iç emniyetle ilgili işlerin idaresini elinde bulunduracaktır. Vali ve Başkumandan, Kraliçe tarafindan tayin edilecek ve Valinin savunma, dış ve iç emniyet konularında kanun yapma yetkisi bulunacaktır. Diğer konularda kararlar 36 üyeli bir parlamento tarafından alınacaktır. Meclisin 6 üyesi Türk cemaati 
arasından, 24'ü de çoğunluk tarafından seçilecektir. (Bunların Rum olacakları anlaşılmaktadır) 6 milletvekili de Vali tarafindan tayin olunacaktır. Bu milletvekillerinden biri İngiliz biri de Mauri olacaktır. Türk azınlığı ilgilendiren eğitim ve diğer meselelerdeki kanunlar, Türk mebusların üçte ikisinin oyu olmaksızın çıkarılamayacaktır. Kıbrıs Türkleri bundan sonra din, eğitim, hayrat ve kültürel müesseselerle ilgili kanunları doğrudan doğruya yapamayacaklardır. Her yıl bir başkan, bir de başkan yardımcısı seçilecektir. Başkan Rum olduğu takdirde başkan yardımcısı Türk olacaktır. Başkan ve yardımcısı oy kullanamayacaktır. Adadaki radyo, televizyon ve mümasil yayın vasitaları tarafsız bir korporasyon idaresine verilecektir (Milliyet, 1956: 1).

İngiliz hükümeti tarafından olduğu gibi kabul edilen ve 19 Aralık 1956'da resmen açıklanan bu tasarıya göre Kıbrıs'a özerklik verilecektir. Ancak özerkliğin uygulanması Adadaki olağanüstü durumun yani tedhişçilik ve düzensizliğin sona ermesine bağlı olacaktır. Ayrıca bu özerklik dışişleri, savunma ve iç güvenlik alanlarının dışında kalacaktır. Bu üç alanda İngiltere'nin ada üzerindeki egemenliği sürecek ve atayacağı vali kesin yetkilere sahip olacaktır. İngiltere bu suretle Kıbrıs'a özerklik vermeyi kabul etmiştir (Uçarol, 1995: 745). Fakat aynı gün İngiltere Sömürgeler Bakanı Lennox Boyd, Kıbrıs Sorununun çözümünde taksimin de bir çözüm yolu olduğunu beyan etmiştir (Değerli, 2012: 95).

Görüldüğü gibi İngiltere hükümeti özerkliği geçici bir dönem ele almıştır. Ayrıca Kıbrıs'ta iki ayrı toplumun varlığını kabul ederek self determinasyon hakkının her iki toplum için de ayrı ayrı tanınması gerektiğini yani adanın taksiminin de bir çözüm yolu olarak ele alınabileceğini belirtmiştir (Uçarol, 1995: 745-746) Böyle bir politika değişikliğinde Süveyş harekâtının İngiltere açısından başarısız olması etkili olmuştur. İngiltere bu harekâttan sonra bölgedeki etkin güç olma konumunu yitirmiş ve 1957 Eisenhower Doktrini ile bölgede Batının çıkarlarını koruma ve kollama görevini ABD'ye devretmiştir. Artık Kıbrıs'ın İngiltere için stratejik değeri azalmıştır. Adada İngiliz üslerinin bulunması askeri açıdan yeterli hale gelmiştir (Fırat, 2002: 604).

$\mathrm{Bu}$ sıralarda uluslararası ilişkilerde sömürgeciliğe karşı güçlenmiş olan akımdan yararlanmak ve tarafsız devletlerin oylarıyla sorunu kendi lehine çözümlemek amacıyla Yunanistan, Kıbrıs sorununu Şubat ve Aralık 1957'de olmak üzere Birleşmiş Milletlere götürmüştür (Uçarol, 1995: 746). Yunanistan'ın bu adımına karşı DP hükümeti bir tedbir düşünmüş ve bu amaçla öncelikle ABD’nin tutumuna önem vermiştir. Bunun sonucunda Fatin Rüştü Zorlu 9 Şubat 1957 tarihinde ABD Dıș İşleri Bakanı Mr. Foster Dulles'i evinde ziyaret etmiştir. Zorlu, Dulles'e Türk görüşünü anlatmış, Dulles ise Yunanistan'da komünistlerin iş başına geleceği korkusuyla Yunan hükümetinin üzerine çok varmak istemediklerini söylemiş̧tir. Zorlu da kendisine asla Yunanistan'da komünist bir hükümetin iş başına gelemeyeceği şeklinde karşılık vermiştir. $\mathrm{Bu}$ görüşmede Birleşmiş Milletlerde, Türkiye'nin Kıbrıs sorununda bir taraf olduğu formülünün $\mathrm{ABD}$ tarafından benimsenmesinin önemi vurgulanmış ve ABD Dış İşleri Bakanına konunun hassasiyeti aktarılmıştır (Koç, 2006: 84).

18 Şubat 1957 'de tartışılmaya başlanan sorun üzerinde Hindistan'ın karar tasarısı Birleşmiş Milletlerde kabul edilmiştir. Buna göre Genel Kurul, Kıbrıs sorununun çözümünün bir barış ve ifade serbestisi ortamının bulunmasını gerektirdiği kanısına vararak, çözümün ilgili taraflar arasında barışçı, adil ve demokratik yollarla bulunmasını arzu eden bir tavsiye kararını kabul etmiştir. Bu kararı Türkiye son derece olumlu karşılamıştır. Ankara'ya göre 
BM, Türkiye'nin Kıbrıs sorununda taraf bir ülke ve Kıbrıs Türk toplumunun eşit hak sahibi bir birim olduğunu resmen tanımış ve Enosis tezini reddetmiştir (Fırat, 2002: 605). Birleşmiş Milletlerde Aralık 1957'de yapılan görüşmeler sonunda ise Yunanistan'in self determinasyon prensibinin Kıbrıs halkına uygulanması isteği 20'ye karşı 33 oyla kabul edilmiştir. Fakat bu karar üçte iki oy çoğunluğunu sağlayamadığı için geçerli olmamıştır. Dolayısıyla Şubat ayında kabul edilen karar yürürlükte kalmıştır (Uçarol, 1995: 747).

Bu sıralarda NATO Genel sekreteri Lord Ismag, İngiltere'ye müracaat ederek Kıbrıs sorununda NATO'nun aracılığını teklif etmiştir. Aynı teklif Türkiye ve Yunanistan'a da yapılmıştır. Türkiye ve İngiltere'nin teklife olumlu cevap vermesine karş1lık Yunanistan yapılan teklifi reddetmiştir. Bu teklifin olgunlaştığı sıralarda Kıbrıs'ta tedhiş hareketleri hız kazanmaya başlamıştır. EOKA'ya karşı büyük bir askeri operasyona girişen İngiltere başarılı olmuş, EOKA liderlerinin birçoğu ya öldürülmüş ya da yakalanmıştır. Bunun üzerine 14 Mart 1957'de EOKA, ateşkes ilan ederek Makarios serbest bırakılırsa Adada tedhiş hareketlerinin durdurulacağını bildirmiştir (Koç, 2006: 84). Süveyş başarısızlığından sonra istifa eden İngiltere Başbakanı Anthony Eden'in yerine gelen Macmillan Hükümeti liberal bir anlayış benimsemiş, 21 Ekim 1957'de üst düzey sömürgeler idarecisi ve liberal yönüyle tanınan Sir Hugh Foot, Harding' in yerine Kıbrıs'a vali olarak atanmıştır. Bu yeni politik anlayış çerçevesinde Makarios'un da sürgün edildiği Seychelles Adası'ndan Atina'ya gelmesine müsaade edilmiştir (Göktepe, 2002: 946) Kısacası Kıbrıs'ta ortamı yumuşattıktan sonra NATO çerçevesinde üçlü görüşmelerin başlatılması için adım atılmıştır (Fırat, 2002: 605). Aralık 1957'de yeni NATO Genel Sekreteri Paul Henri Spaak'ın israrlarıla Türkiye ve Yunanistan başbakanları ile İngiltere Dış İşleri Bakanı arasında Kıbrıs konusu ele alınmış, fakat yine bir uzlaşma sağlanamamıştır (Uçarol, 1995: 747).

1958 yılı Ada'da tedhişçiliğin giderek hızlandığı yıl olarak Kıbrıs'ta durumun adamakıllı kötüleşmesine paralel şekilde Türk-Yunan ve Türk-İngiliz ilişkilerinin gerginleştiği bir dönem olmuştur (Koç, 2006: 84). EOKA, Rumları Türklere karşı hücuma çağırmış, Türk kadınları tecavüze uğramış ve Kıbrıs Türkleri Türkiye'den yardım istemişlerdir (Hürriyet, 1958: 1).

İngiltere, 19 Haziran 1958 tarihinde yeni bir planı, Macmillan Planı'nı öne sürmüştür (Firat, 2002: 606). Yeni plan, taksimi benimseyerek Ada'da 7 yıllık bir muhtariyet prensibini kabul etmiştir. Plan İngiltere tarafından NATO Konseyine getirilip bazı değişikliklere uğramış ve ortaklık yerine Türkiye, Yunanistan ve İngiltere'ye garantörlük verilmiştir (Hakk1, 2006: 31).

Başpiskopos Makarios, 22 Eylül 1958'de Kıbrıs'a öngörülen zamandan önce bağımsızlık verilmesini önermiş ve doğal olarak bu öneri DP hükümeti tarafından bir son dakika denemesi olarak yorumlanmış ve reddedilmiştir. DP, temel hakları İngiliz hükümeti tarafından önerilmesi gereken bir üçlü konferansın toplanması taraftarı olduğunu bildirmiştir (Bağc1, 2007: 124).

1958 yılında Türk kamuoyunda işlenen tez ise "Ya taksim Ya Ölüm" olmuştur. Yurdun çeşitli yerlerinde bu amacı belirtmek üzere mitingler yapılmış ve Türk kamuoyunun heyecanı yükselmiştir. Kıbrıs'ta da Rum tedhişçiliği had safhasına çıkmıştır. Bu durum Türk-Yunan ilişkilerini gerginleştirince NATO'nun Doğu Akdeniz'deki sağ kanadı sarsılmıştır. Bundan dolayı bir yandan ABD'nin, diğer yandan da NATO'nun baskısı ve 
aracıllğı ile Türkiye ve Yunanistan arasında ikili görüşmelere girişilmiştir (Armaoğlu, 2000: 533).

\section{1. Zürih ve Londra Antlaşmaları}

Yunanistan, 1958 yılı sonlarında Kıbrıs Sorununu yeniden Birleşmiş Milletler'e götürmüştür. Fakat Birleşmiş Milletler, 5 Aralık 1958'de anlaşmazlığın taraflar arasında görüşmelerle çözümlenmesini tavsiye etmeye karar vermiştir (Uçarol, 1995: 747). NATO'nun da etkisiyle bütün yıl boyunca soğuk kalan Türk-Yunan atmosferi de 1sınmaya başlamıştır. Üç ülkenin dışişleri bakanları 18 Aralık 1958 tarihinde bir araya gelerek Kıbrıs'ın bağımsızlığı temeli üzerine oturacak, Taksim ve Enosis'e karşı garantiler sunacak olan bir üçlü konferansın yapılmasına karar vermişlerdir. Bu karar üzerine Fatin Rüştü Zorlu ile Yunan Dış İşleri Bakanı Avangelos Averof, NATO toplantısı için Paris’te bulundukları bir sırada bir araya gelerek Zürih ve Londra Antlaşmalarının hazırlıklarını yapmışlardır. Antlaşmanın kabataslağında anlaşan Türk ve Yunan delegasyonlarının birlikte yedikleri öğle yemeğinde Averof bardağını kaldırarak 'Müssterek gayretlerimizin başarısına' derken Zorlu'nun buna cevab1 'Türk-Yunan Dostluğuna' şeklinde olmuştur. Averof ise 'Bütün kalbimle katıllyorum' şeklinde Zorlu'ya karşıllk vermiştir (Bağc1, 2007: 125)

Hazırlıklar tamamlandıktan sonra Başbakan Menderes, Yunanistan Başbakanı Konstantin Karamanlis, Zorlu ve Averof 6 Şubat 1959'da Zürih'te bir araya gelmişlerdir. 11 Şubat'ta da ortak bir bildiri yayınlayarak Bağımsız Kıbrıs Cumhuriyeti'nin kurulması, yönetimin anayasal çerçevesini ortaya koyan Kıbrıs Cumhuriyeti'nin Temel Yapısına ilişkin şartlarda Türkiye ve Yunanistan'ın anlaştığı duyurulmuştur (Firat, 2002: 609). Zürih Antlaşması ile ilgili olarak Menderes günlügüne, "Kıbrıs için artık garantör bir devlet olduk. Anlaşma hükümlerine göre Klbrıs'ta bir Rum Cumhurbaşkanı bir de Türk yardımcısı olacak. Kıbrıs bağımsız bir devlet haline geliyor" (Tuna, 2010: 253) ifadelerini not düşmüştür.

Ardından bu anlaşma metinlerinin İngiltere ve Kıbrıs'taki iki toplum tarafindan imzalanması aşamasına geçilmiştir. $\mathrm{Bu}$ aşama ise Londra Konferansı'nda gerçekleştirilecektir. Ancak Makarios, başlangıçta Zürih Antlaşmasını itirazsız kabul etmesine rağmen yalnızca Enosis taraftarı olan EOKA'nın baskısından dolayı Londra Konferansı'nın toplandığı 17 Şubat'tan bir gün önce Averof'a Rum temsilcileri ikna edemediğini ve Zürih'te kabul edilen metinler değiştirilmediği takdirde imzalamayacağını söylemiş̧ir. Bu tavra karşı Karamanlis, kendisinin antlaşma metinlerini imzalayacağını, Kıbrıslı Rumların bundan sonra Yunanistan olmadan mücadelelerini sürdürebileceklerini belirtmiştir. Makarios, 18 Şubat'ta antlaşma metinlerini imzalamak için değil de görüşmek için Londra'ya geldiğini söyleyince İngiltere Dış İşleri Bakanı Lloyd ertesi gün saat 09.45'e kadar kesin kararını bildirmesi için ona süre tanımıştır. Kendi deyimiyle hayatının en zor ve en uzun gecesini geçiren Makarios, 19 Şubat'ta olumlu yanıt verince imza işlemleri tamamlanmıştır. Londra'ya giderken uçağı düştügüu için hastanede bulunan Menderes'e gidilerek imzası alınmıştır (Fırat, 2002: 609-610). Üçlü Londra Konferansı sürecinde yaşanan gelişmeler İstanbul'daki bir kısım basın tarafından da yakından takip edilmişsir (Yeni İstanbul, 1959: 1).

Zürih ve Londra Antlaşmalarına göre Cumhurbaşkanı Rum, yardımcısı Türk olacaktır. Bakanlar Kurulu 7 Rum, 3 Türk üyeden, Temsilciler Meclisi 35 Rum, 15 Türk üyeden oluşacaktır (Koç, 2006: 102). Zürih ve Londra Antlaşmaları bağımsız Kıbrıs ile 
Türkiye, Yunanistan ve İngiltere arasında organik münasebetler ve bağlar kurmuştur. Bu bağlardan biri olan Garanti Antlaşmasına göre Kıbrıs Cumhuriyeti, anayasal düzeni bütün ayrıntıları ile korumayı taahhüt etmiştir. Yine Anayasanın ayrılmaz parçasını teşkil eden İttifak Antlaşması'na göre Yunanistan Kıbrıs'ta 950 kişilik Türkiye de 650 kişilik bir askeri kuvvet bulundurmak hakkına sahip olmuşlardır. Anlaşmalarla Enosis ve taksim yasaklanmıştır. Bu esaslar çerçevesinde hazırlanan Kıbrıs Anayasası 16 Ağustos 1960’ta yürürlüğe girerek Kıbrıs Cumhuriyeti resmen kurulmuştur (Armaoğlu, 2000: 533-534). İngiltere, Batı dünyası için gerekli olan üslerine sahip kalırken Türk ve Yunan veto hakkı üzerine kurulan anayasal denge, komünizm tehlikesine karşı en sağlam çifte garanti olarak addedilmiştir (Hakkı, 2006: 31).

Kıbrıs’ta ilk Cumhurbaşkanlığı seçimi 13 Aralık 1959 Pazar günü yapılmıştır. 265 bin Rum oyunun 144 binini alan (Koç, 2006: 105). Başpiskopos Makarios, Kıbrıs Cumhurbaşkanı olmuştur (Son Posta, 1959: 1). Cumhurbaşkanı Yardımcısı ise Dr. Fazıl Küçük olmuştur (Koç, 2006: 106).

\section{Sonuç}

Türk siyasi tarihinde bir döneme damgasını vuran Demokrat Parti'nin Kıbrıs politikası iktidarda kaldığı 10 yıllık dönemde dört kez değişmiştir. Bu değiş̧ikliklerin bir gerekçe ile yapıldığı görülmüştür. DP'nin uyguladığı ilk politika, İngiltere'nin egemenliğinin Kıbrıs'ta devam ettirilmesi yani mevcut durumun devamı olmuştur. $\mathrm{Bu}$ minvalde DP, Kıbrıs'ın Lozan Barış Antlaşması ile İngiltere'ye devredilen bir toprak parçası olması gerçeğinden hareketle, Adada her hangi bir statüko değişikliğini öngörmemiştir. İkinci olarak 6-7 Eylül Olaylarından sonra, İngiltere Kıbrıs'tan çekilebileceği düşüncesini ortaya atınca DP, İngiltere'nin Kıbrıs'tan ayrılması durumunda Adanın tekrar Türkiye'ye kazandırılması tezini benimsemiş ve bu doğrultuda adımlar atmaya başlamıştır. Bu politika 1956'ya, daha doğrusu Radcliffe Anayasası'nın gündeme getirilmesine kadar devam etmiştir. Radcliffe Anayasası ile İngiltere, self determinasyon hakkının her iki Kıbrıs halkına da tanınabileceğini belirtince DP, politikasını üçüncü kez değiştirip bu sefer taksim tezini benimsemiştir. DP, dördüncü ve son olarak da Zürih ve Londra Antlaşmaları ile bağımsız Kıbrıs Cumhuriyeti'nin kurulmasını kabul etmiştir. Genel olarak bakıldığında DP, Yunanistan'ın Enosis tezini çürüterek ortadan kaldırmış, Kıbrıs Rumlarının tek başlarına Adada bağımsız bir devlet kurmalarına engel olmuştur. Londra ve Zürih Antlaşmalarında Türkiye, İngiltere ve Yunanistan bir anlamda Adada barışın tesisi noktasında inisiyatif sahibi garantör devletler konumuna gelmiştir. Yine bu antlaşmalarda Adada iki toplumun nüfus oranına göre bir yönetim paylaşımı planlanmış ve aynı minvalde kurulan Kıbrıs Cumhuriyeti'nde Cumhurbaşkanı bir Rum olurken, yardımcısı da bir Türk olarak belirlenmiştir. Yine bakanların ve milletvekillerinin yönetimdeki dağılımları da iki toplumun nüfus oranına göre teşkil edilmiştir. Ancak yönetimin bu şekilde düzenlenmiş olması, bazı araştırmacıların Rum tarafının Adadaki hakimiyetini pekiştirdiği iddiası ile eleştirilmiştir. Londra ve Zürih Antlaşmaları çerçevesindeki bu olumlu ve olumsuz eleştiriler göz önüne alındığında, son tahlilde DP'nin Kıbrıs'ta Enosis planını bertaraf edip iki toplumlu yönetimin sağlanmasında gösterdiği çaba, başarılı bir politika olarak değerlendirilebilir. 


\section{Kaynakça}

Resmi Yayınlar

TBMM Zabıt Ceridesi, Devre: X, Cilt I, İçtima: 1, 80. Birleşim.

Gazeteler

Hürriyet, 13 Haziran 1958.

İstanbul Ekspres, 6 Eylül 1955, İkinci Bask1.

Milliyet, 19 Ekim 1960.

Milliyet, 20 Aralık 1956.

Milliyet, 20 Ekim 1960.

Milliyet, 22 Ekim 1960.

Milliyet, 7 Eylül 1955, İkinci Bask1.

Son Posta, 15 Aralik 1959.

Tan, 13 Eylül 1955.

Yeni İstanbul, 18 Şubat 1959.

\section{Kitaplar}

Akın, F. (2006). Türkiye'de Azınlık Politikaları ve 6-7 Eylül Olayları, İstanbul: Kum Saati Yayınları.

Alasya, H. F. (1988). Tarihte Kıbrıs, Ankara: Kıbrıs Türk Kültür Derneği Yayınları.

Armaoğlu, F. (1963). Kıbrıs Meselesi 1954-1959, Ankara: Sevinç Matbaas1.

Armaoğlu, F. (2000). 20. Yüzyll Siyasi Tarihi (1914-1995), C.I-II, 12. Bask1, İstanbul: Alkım Yayınları.

Bağcı, H. (2007). Türk Dış Politikasında 1950'li Yıllar, Ankara: ODTÜ Geliştirme Vakfı Yayinları.

Cam, Ö. (1966). Anadolu Kokan Kıbrıs, Ankara: Ankara Yayınları.

Demirer, M. A. (2006). 6 Eylül 1955 Olaylarına 50. Yılda Yeni Bakış, Ankara: Demokratlar

Kulübü Yayınları.

Dikerdem, M. (1977). Ortadoğu'da Devrim Yılları, İstanbul.

Dosdoğru, M. H. (1993). 6/7 Eylül Olayları, İstanbul: Bağlam Yayınları.

Güven, D. (2009). 6/7 Eylül Olayları, İstanbul: İletişim Yayınları.

Hakkı, M. M. (2006). Kıbrıs Çıkmazı, İstanbul: Emre Yayınları.

Karakuş, E. (1977). Işste Ankara, İstanbul: Hürriyet Yayınları.

Keser, U. (2007). Kıbrıs Yeraltı Faaliyetleri ve Türk Mukavemet Teşkilatı, İstanbul: IQ

Kültür Sanat Yayıncilık.

Koç, R. (2006). Kıbrıs Basınında Kıbrıs Olayları, İstanbul: Doğu Kütüphanesi Yayınları.

Manisal1, E. (2012). Dünden Bugüne Kıbrıs, Ankara: Gençlik Cephesi Yayınları.

Meray, S. L. (2001). Lozan Barış Konferansı Tutanaklar Belgeler, C. 8, İstanbul: Yapı Kredi Yayınları.

Oran, B. (2009). Türk Dış Politikası Kurtuluş Savaşından Bugüne Olgular Belgeler

Yorumlar, 15. Baskı, İstanbul: İletişim Yayınları.

Sakin, S., Dokuyan, S. (2013). Kıbrls ve 6-7 Eylül Olaylarl (Menderes ve Zorlu'nun Tarihi

Sinavı), 2. Bask1, İstanbul: IQ Kültür Sanat Yayınlar1.

Tuna, T. (2010). Adnan Menderes' in Günlüğü Siyasete Karışan Kan, 5. Bask1, İstanbul: Şûle Yayınları.

Uçarol, R. (1995). Siyasi Tarih (1789-1994), 4. Bask1, İstanbul: Filiz Kitabevi.

Zia, N. (1975). Kıbrıs'ın İngiltere'ye Geçişi ve Adada Kurulan İngiliz İdaresi, Ankara: Türk Kültürünü Araştırma Enstitüsü Yayınlarl.

\section{Kitap Bölümü}


Fırat, M. (2002). “Yunanistan’la İlişkiler”, Türk Dış Politikası, C. I, (Editör: Baskın Oran), İstanbul: İletişim Yayınları.

\section{Makaleler}

Değerli, E. S. (2012). “Demokrat Parti Döneminde Türkiye’nin Kıbrıs Politikası (19501960)", Gazi Akademik Bakış, 6(11): 85-101.

Kapcı, H. Z., Sakin, S. (2015). "Cumhuriyet Arşivi Işı̆̆ında Yabancıların Bakış Açısıyla Türkiye'nin Kibrıs Politikas1 (1955-1959)", The Journal of Academic Social Science Studies (JASSS), 34(2): 137-153.

Yüksel, D. Y. (2011). "İngiliz Büyükelçiliği Yıllık Raporlarında Türkiye'de Demokrat Parti (1954-1957)”, Atatürk Araştırma Merkezi Dergisi, XXVII (79): 161-184.

\section{Ansiklopedi Maddesi}

Göktepe, C. (2002). "Londra ve Zürih Antlaşmalarının Hazırlık Süreci ve Türk İngiliz İlişkileri (1955-1959)", Türkler, C. 16: 943-951. 